Tropical Journal of Pharmaceutical Research November 2016; 15 (11): 2345-2350

ISSN: $1596-5996$ (print); 1596-9827 (electronic)

(C) Pharmacotherapy Group, Faculty of Pharmacy, University of Benin, Benin City, 300001 Nigeria.

All rights reserved.

Available online at http://www.tjpr.org

Original Research Article

http://dx.doi.org/10.4314/tjpr.v15i11. 7

\title{
Generation of truncated recombinant form of tumor necrosis factor receptor-1 to produce cancer vaccine
}

\author{
Hamide Hatamihanza1, Mehrdad Hashemi ${ }^{1 *}$, Azim Akbarzadeh², Fatemeh \\ Fotouhi $^{3}$, Behrokh Farahmand ${ }^{3}$, Hasan Ebrahimi Shahmabadi ${ }^{4}$ \\ ${ }^{1}$ Department of Molecular Genetics, Tehran Medical Branch, Islamic Azad University, ${ }^{2}$ Department of Pilot Nanobiotechnology, \\ ${ }^{3}$ Department of Virology, Influenza Research Lab, Pasteur Institute of Iran, ${ }^{4}$ Department of Microbiology, School of Medicine, \\ Rafsanjan University of Medical Sciences, Rafsanjan, Iran
}

*For correspondence: Email: mhashemi@iautmu.ac.ir; Tel: 009822006660; Fax: 009822008049

Received: 18 May 2016

Revised accepted: 11 October 2016

\begin{abstract}
Purpose: To produce truncated recombinant form of tumor necrosis factor receptor 1 (TNFR1), cysteine-rich domain 2 (CRD2) and CRD3 regions of the receptor were generated using $p E T 28 a$ and E. coli/BL21.

Methods: DNA coding sequence of CRD2 and CRD3 was cloned into $p E T 28 a$ vector and the corresponding protein was expressed under induction of isopropyl $\beta$ - $D$-1-thiogalactopyranoside (IPTG) as $6 \times$ His tagged using E.coli BL21 (DE3) expression system. The protein was then purified by Ni-NTA affinity chromatography. The fragment insertion, expression of recombinant protein and the yield of expression were evaluated.

Results: Protein expression was achieved by identifying a band with molecular weight of $1488.3 \mathrm{Da}$. The recombinant protein of CRD2 and CRD3 was most efficiently expressed in $0.5 \mathrm{mM}$ IPTG and $3 \mathrm{~h}$ of incubation at $37{ }^{\circ} \mathrm{C}$ with high yield equal to $0.3 \mu \mathrm{g} / \mu \mathrm{l}$. Also, the highest concentration of imidazole for purification of the recombinant protein was $250 \mathrm{mM}$.

Conclusion: A truncated form of TNFR-1 has been successfully expressed in a bacterial expression system and purified on affinity column. The purified protein can be used in in vivo experiments to prepare specified agonist antibodies for TNFR-1.
\end{abstract}

Keywords: Tumor necrosis factor receptor 1 (TNFR-1), Cysteine rich domain 2 (CRD2), Cysteine rich domain (CRD3), Apoptosis, Cancer vaccine, Antibodies, Recombinant protein, pET28a

Tropical Journal of Pharmaceutical Research is indexed by Science Citation Index (SciSearch), Scopus, International Pharmaceutical Abstract, Chemical Abstracts, Embase, Index Copernicus, EBSCO, African Index Medicus, JournalSeek, Journal Citation Reports/Science Edition, Directory of Open Access Journals (DOAJ), African Journal Online, Bioline International, Open-J-Gate and Pharmacy Abstracts

\section{INTRODUCTION}

Tumor necrosis factor- $\alpha$ (TNF- $\alpha$ ) is a multifunctional cytokine with various roles in inflammation, immunity, cell proliferation, differentiation and apoptosis [1]. TNF- $\alpha$ exists in two forms: transmembrane and soluble which exert their effects through binding and activating two TNF family receptors: TNF receptor 1 (TNFR1) and TNF Receptor 2 (TNFR2) [2]. Many studies have been conducted on antitumor functions of the receptors [3]. The major difference between the two receptors has been reported to be the presence of a death domain in TNFR1 and absence of a death domain in TNFR2 [4]. TNF has been found to activate proapoptotic signaling cascade through TNFR1 [5] which is expressed in various types of cells, tissues [6] and tumors [7]. Studies have shown that antibodies against TNFR1 mimic the effect of TNF- $\alpha[8,9]$ and as a result initiate the apoptosis process. The extracellular region of the 
receptor consists of four cysteine-rich domains (CRDs): CRD1, CRD2, CRD3, CRD4. CRD2 and CRD3 play important roles in ligand binding [10]. TNF- $\alpha$ binding to TNFR1 induces receptor trimerization and recruitment of various signaling proteins. TNFR1 transduces apoptotic and antiinflammatory signals via the employment of FASassociated death domain protein (FADD) and further recruitment of caspase-8. Activated caspase-8 triggers a proteolytic cascade that entangles caspases- $3,-6$ and -7 , eventually inducing apoptosis. Also TNFR-1 mediates antiapoptotic and inflammatory responses like activation of the necrosis factor (NF)-KB by employing TNF-receptor-associated factor 2 (TRAF2) and receptor-interacting protein 1 (RIP1) [11]. Therefore, inhibition of NF-KB activity enhances TNF- $\alpha$-induced cell death while an increase in NF-KB activity protects the cells from TNF- $\alpha$-induced death [12].

In this study, CRD2 and CRD3 regions in a $p E T$ vector were cloned using E.coli/BL21 and expressed. Various techniques including agarose gel electrophoresis, sodium dodecyl sulfate polyacrylamide gel electrophoresis (SDS-PAGE), western blot, Ni-NTA chromatography, dialysis membrane, and Bradford were used.

\section{EXPERIMENTAL}

\section{Materials}

Diaminobenzidine (DAB) was purchased from Sigma Company (USA). Acrylamide, sodium dodecyl sulfate and agarose were obtained from Merck Company (Germany). Original pET28a and recombinant $\mathrm{pET} 28 \mathrm{a}$ plasmid were gifted and E.coli/BL21 was prepared from Pasteur Institute of Iran, Tehran. BamHI, Sal I, restriction enzymes and T4 DNA Ligase were purchased from Fermentas Company (Finland). DNA extraction kit and Ni-NTA agarose resin were obtained from Bioneer Company (South Korea) and Qiagen Company (Germany), respectively. Distilled water was used throughout the experiment. All materials were of analytical grade.

\section{Cloning of CRD2 and CRD3}

Recombinant pET28a plasmid resistance to kanamycin, containing CRD1, CRD2, CRD3 and CRD4 was transferred into susceptible bacteria (E.coli/BL21) by chloride calcium and heat shock methods. For this purpose, cultured bacteria in the log phase $(O D=0.4)$ were centrifuged $(9000$ rpm, $3 \mathrm{~min}$ ) and sediment was obtained. The sediment was mixed with $1 \mathrm{~mL} 0.1 \mathrm{M}$ cold calcium chloride, and placed on ice for $30 \mathrm{~min}$ and then centrifuged. The supernatant was then discarded and the process was repeated. The suspension of bacteria was then incubated with recombinant vector $(1.5 \mu \mathrm{l}, 60 \mathrm{ng} / \mu \mathrm{l})$ on ice for 30 $\mathrm{min}$. The mixture was shocked with temperature $\left(42{ }^{\circ} \mathrm{C}, 90 \mathrm{~s}\right)$ and placed on ice for $2 \mathrm{~min}$, followed by culturing into $1 \mathrm{ml}$ liquid LB culture medium in $37^{\circ} \mathrm{C}$.

After $1 \mathrm{~h}, 500 \mu \mathrm{L}$ of medium was taken and cultured on the plate of LB medium containing kanamycin $\left(37{ }^{\circ} \mathrm{C}, 18 \mathrm{~h}\right)$. The recombinant plasmid was extracted and the fragment containing CRD2 and CRD3 was obtained using BamH1 and SA1 I restriction enzymes. Next, the fragment was run on agarose gel electrophoresis and then obtained using DNA extraction kit. It was then inserted into original pET28a plasmid after excision of vector by BamH1 and SA1 I restriction enzymes. The fragment was ligated to vector using T4 DNA ligase and transferred into susceptible bacteria. To verify the insertion of fragment into plasmid, the plasmid was extracted and digested by the two restriction enzymes and run on agarose gel electrophoresis.

\section{Induction of protein expression}

Isopropyl $\quad \beta$-D-1-thiogalactopyranoside (IPTG) was used to induce the expression of recombinant protein. In pET28a vector, T7 promoter is responsible for the transcription of the inserted fragment. Although recombinant bacteria were cultured in liquid LB culture medium containing kanamycin in a shaker incubator $\left(37^{\circ} \mathrm{C}, 180 \mathrm{rpm}\right)$. After $3 \mathrm{~h}$, various concentrations of IPTG were added to the medium. In various time intervals of 2,3 and $4 \mathrm{~h}$ after induction by IPTG, sampling was performed. The total protein was extracted by sonication on ice [13]. In addition, western blotting technique was used to detect the expression of recombinant protein.

\section{Scale up of recombinant protein}

The recombinant protein was produced on a large scale using one-liter Erlenmeyer flask and shaker incubator $\left(37{ }^{\circ} \mathrm{C}, 180 \mathrm{rpm}\right)$. Ni-NTA affinity chromatography technique was used to purify the protein. Bradford method was used to estimate the concentration of protein.

\section{Statistical analysis}

The data were statistically analyzed by one-way analysis of variance (ANOVA) using IBM Statistics SPSS software version 19, and statistical significance was set at $p<0.05$. The 
results are expressed as mean \pm standard deviation (SD, $\mathrm{n}=3$ ).

\section{RESULTS}

\section{Cloning of CRD2 and CRD3}

Evaluating the growth of recombinant bacteria containing CRD1, CRD2, CRD3 and CRD4 confirmed bacterial transformation (i.e. growth of antibiotic-resistance versus no growth of antibiotic-sensitive). Also, the insertion of the regions into plasmid was confirmed by agarose gel electrophoresis (Figure 1).

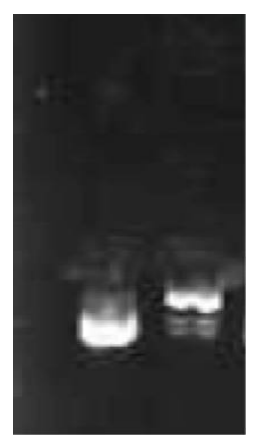

Figure 1: Agarose gel electrophoresis of original (left column) and recombinant vector (right column). The difference in the movement between two plasmids confirmed the insertion of fragment containing CRD1, CRD2, CRD3 and CRD4 into vector.

In addition, bacterial transformation with recombinant plasmid containing CRD2 and CRD3 was confirmed. For this purpose, plasmid extraction was performed and excised by BamH1 and SA1 I restriction enzymes and then run on agarose gel electrophoresis. The fragment related to CRD2 and CRD3 was demonstrated on the gel (Figure 2).

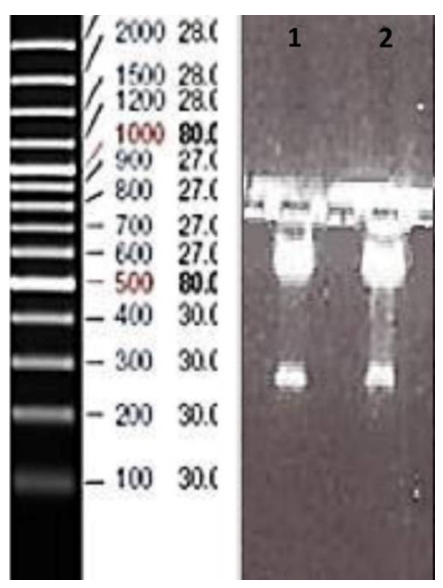

Figure 2: Agarose gel electrophoresis of DNA fragment containing CRD2 and CRD3 with 264 bp (columns 1 and 2)

\section{Induction of protein expression}

The recombinant protein was successfully expressed and detected (Figure 3).

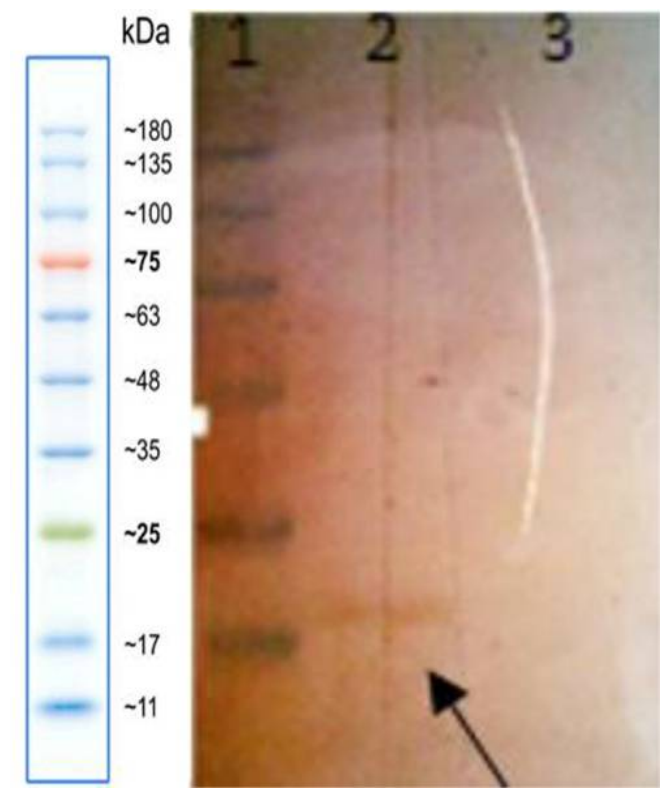

Figure 3: Western blot technique to confirm the expression of recombinant protein. 1) protein marker, 2) the expressed recombinant protein after induction by IPTG, and 3) the expressed recombinant protein before induction by IPTG

In addition, the optimum condition for protein production was $3 \mathrm{~h}$ incubation with $0.5 \mathrm{mM}$ IPTG.

To extract the recombinant proteins from bacteria cultured in erlenmeyer flasks, $8 \mathrm{M}$ urea and sonication (Bandelin Sonopuls HD 2070, Bandelin Elec., Germany) (3 min, $50 \mathrm{~W}$ ) were used and the samples were run on SDS-PAGE (Figure 4).

To purify the protein, Ni-NTA affinity chromatography was performed using a gradient of imidazole concentration. It was found that an elution buffer with concentration of $250 \mathrm{mM}$ of imidazole was the most appropriate buffer for protein purification (Figure 5).

In addition, to purify the recombinant protein from urea and salt impurities, dialysis membrane (Cut off $2000 \mathrm{Da}$, Sigma) was used and the protein was run on SDS-PAGE (Figure 6).

Finally, evaluating the concentration of the recombinant protein by Bradford technique confirmed high yield production equal to 0.3 $\mu \mathrm{g} / \mu \mathrm{L}$. 


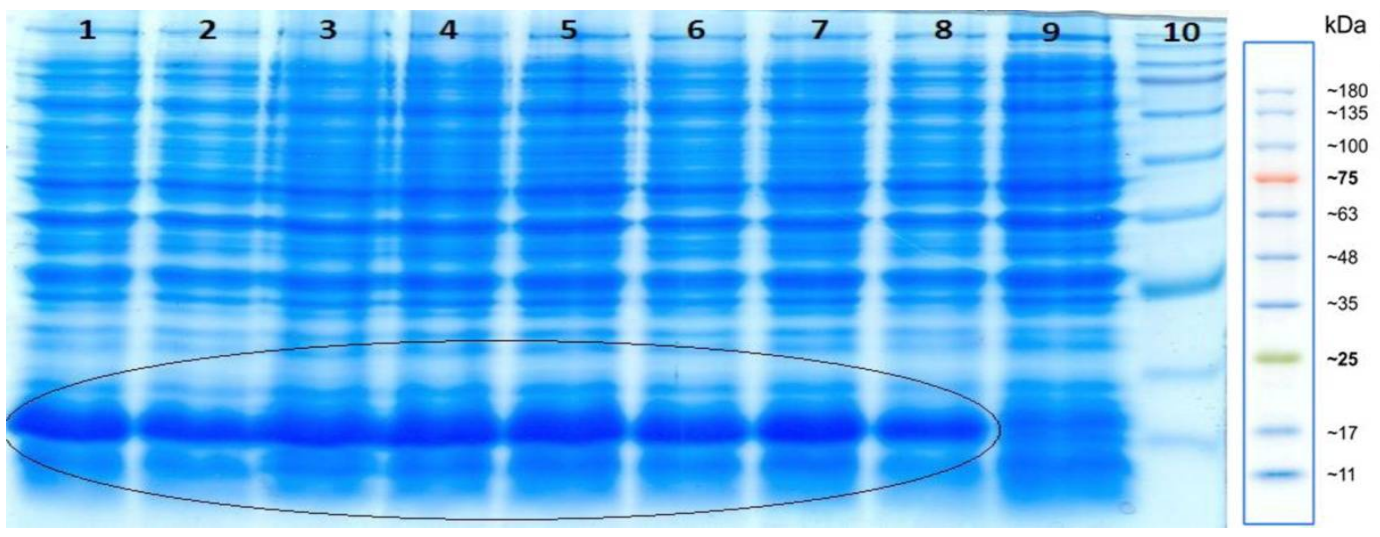

Figure 4: SDS-PAGE of extracted recombinant proteins from four Erlenmeyer flasks. Columns 1 to 8 show the proteins after induction by various concentrations of IPTG in different time intervals. Columns 1 to 3 show target proteins after $4 \mathrm{~h}$ induction with $0.25,0.5$ and $1 \mathrm{mM}$ of IPTG, respectively. Columns 4 and 5 demonstrate the target proteins after $3 \mathrm{~h}$ induction with 0.25 and $0.5 \mathrm{mM}$ of IPTG, respectively. Columns 6 to 8 display the proteins after $2 \mathrm{~h}$ induction with $0.25,0.5 \mathrm{mM}$ and $1 \mathrm{mM}$ of IPTG, respectively. Column 9 presents proteins before induction, and column 10 shows the marker protein

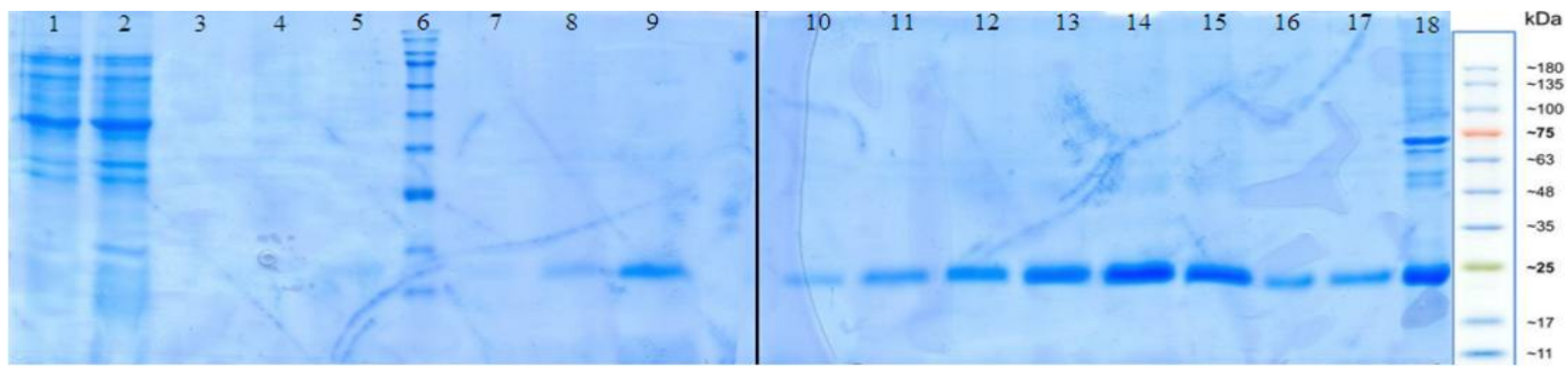

Figure 5: SDS-PAGE of purified recombinant proteins. An elution buffer was used with various concentrations of imidazole. The columns show the expressed protein of CRD2 and CRD3 regions extracted by various concentrations of imidazole solution. The protein shown in columns 1,2 and 3 is extracted with $50 \mathrm{mM}$ imidazole. Columns 4, 5 and 7 present the protein extracted with $100 \mathrm{mM}$ imidazole. Columns 8 and 9 show the extracted protein with $150 \mathrm{mM}$ imidazole and columns 10-15 present extracted protein with $250 \mathrm{mM}$ imidazole. Column 6 shows the marker protein. Columns 16 and 17 are the recombinant proteins extracted twice with $0.5 \mathrm{ml}$ of 250 $\mathrm{mM}$ and $500 \mathrm{mM}$ imidazole, respectively. Column 18 is the sediment of bacteria containing the recombinant protein

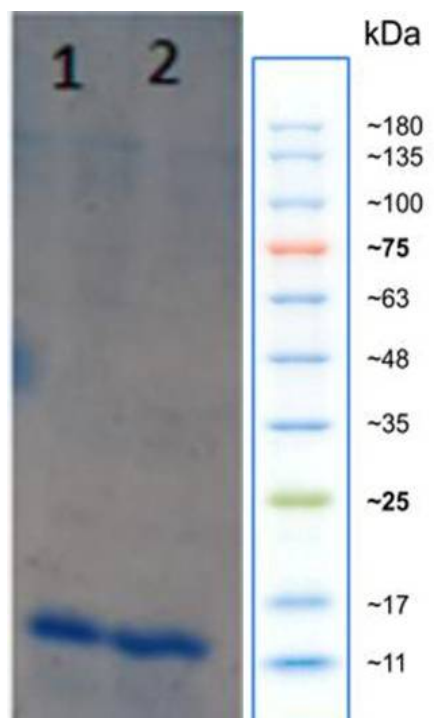

Figure 6: SDS-PAGE of the recombinant protein extracted by Ni-NTA chromatography before dialysis (column 1) and after dialysis (column 2)

\section{DISCUSSION}

There are different reports on the association between TNF protein family and human disorders such as cancers, immunogenic diseases, cardiovascular, nervous system, lung and metabolic disorders [4]. TNF- $\alpha$ induces cell apoptosis through binding to its receptor TNFR-1 [5]. Various studies have confirmed the tumor suppressive effects of TNFR-1 [3,14]. These effects can be induced by agonistic antibodies specific for TNFR-1 [15]. Therefore, in this study we aimed to construct recombinant protein of CRD2 and CRD3 for the preparation of a specific antibody against TNFR-1. Antibodies specific for TNFR1 can be obtained through antigenic properties of receptor.

It has been demonstrated that two domains of TNFR-1, including CRD2 and CRD3, play a vital role in binding to ligands [10]. DNA coding sequence for the domains was then inserted into 
pET28a plasmid and transferred into competent bacteria $E$. coli/BL21. E. coli was chosen because of its appropriate properties for recombinant protein production such as rapid growth in simple and cheap media, well-known genetic information, availability of various types of vectors including cloning and expressing vectors, easy control and possibility of high recombinant protein production [16]. Evaluating the growth of bacteria in culture medium confirmed bacteria transformation. Also, the construction of plasmid containing CRD2 and CRD3 regions was shown by plasmid extraction and excision with BamH1 and Sal 1 enzymes and their appearance on the agarose gel electrophoresis.

In addition, the construction of the plasmid, containing CDR2 and CDR3 was reported by Jian et al [17]. They ligated the fragments to pGEX-3 X plasmid, transferred it into $E$. coli $\mathrm{DH} 5 \alpha$, and expressed it under induction of 0.25 mM IPTG [17]. Furthermore, scale up of recombinant protein production was accomplished with high yield equal to $0.3 \mu \mathrm{g} / \mu \mathrm{L}$.

\section{CONCLUSION}

The recombinant protein of CRD2 and CRD3 regions of TNFR1 which can be used for the production of their specific antibodies was successfully produced. It has been observed to stimulate the expressed TNFR1 in cancer cells as well as triggers apoptotic pathways. In addition, it has been found the pET28a plasmid and E. coli/BL21 are appropriate for the production of recombinant protein, containing CRD2 and CRD3 regions of TNFR1.

\section{DECLARATIONS}

\section{Acknowledgement}

This study resulted from M.Sc thesis which carried out with personal funding in Department of Pilot Nanobiotechnology at the Pasteur Institute of Iran, Tehran and the authors would like to thank all colleagues who have contributed.

\section{Conflict of Interest}

No conflict of interest associated with this work.

\section{Contribution of Authors}

The authors declare that this work was done by the authors named in this article and all liabilities pertaining to claims relating to the content of this article will be borne by them.

\section{Open Access}

This is an Open Access article distributed under the terms of the Creative Commons Attribution License, which permits unrestricted use, distribution, and reproduction in any medium, provided the original work is properly credited.

\section{REFERENCES}

1. Amrani Y, Ammit AJ, Panettieri RA. Tumor Necrosis Factor Receptor (TNFR) 1, but Not TNFR2, Mediates Tumor Necrosis Factor-a-Induced Interleukin-6 and RANTES in Human Airway Smooth Muscle Cells: Role of p38 and p42/44 Mitogen-Activated Protein Kinases. Mol Pharmacol 2001; 60: 646-655.

2. Banner DW, D'Arcy A, Janes $W$, Gentz $R$, Schoenfeld HJ, Broger C, Loetscher H, Lesslauer W. Crystal structure of the soluble human $55 \mathrm{kd}$ TNF receptorhuman TNF $\beta$ complex: implications for TNF receptor activation. Cell 1993; 73: 431-445.

3. Cabal-Hierr L, Lazo PS. Signal transduction by tumor necrosis factor receptors. Cell Signal 2012; 24: 12971305.

4. Dong Y, Dekens DW, De Deyn PP, Naudé PJ, Eisel UL. Targeting of Tumor Necrosis Factor Alpha Receptors as a Therapeutic Strategy for Neurodegenerative Disorders. Antibodies 2015; 4: 369-408.

5. Engelmann H, Holtmann H, Brakebusch C, Avni YS, Sarov I, Nophar Y,Hadas E, Leitner O, Wallach D. Antibodies to a soluble form of a tumor necrosis factor (TNF) receptor have TNF-like activity. J Biol Chem 1990; 265: 14497-14504.

6. Fischer $R$, Kontermann RE, Maier $O$. Targeting sTNF/TNFR1 Signaling as a New Therapeutic Strategy. Antibodies 2015; 4: 48-70.

7. Hashemi M, Amirijavid S, Entezari M, Shafaroodi $H$, Saghafi Z. Generation and characterization of chicken egg yolk antibodies (IgY) against TNFR1. Bratisl Med J 2014; 116: 316-320.

8. Jian J1, Zhao S, Tian Q, Gonzalez-Gugel E, Mundra JJ, Uddin SM, Liu B, Richbourgh B, Brunetti R, Liu CJ. Progranulin directly binds to the CRD2 and CRD3 of TNFR extracellular domains. FEBS Lett 2013; 587: 3428-3436.

9. Laegreid A, Medvedev A, Nonstad U, Bombara $M$, Ranges G, Sundan A, Espevik T. Tumor necrosis factor receptor p75 mediates cell-specific activation of nuclear factor kappa $B$ and induction of human cytomegalovirus enhancer. J Biol Chem 1994; 269: 7785-7791.

10. Makrides SC. Strategies for achieving high-level expression of genes in Escherichia coli. Microbiol Rev 1996; 60: 512-538.

11. Miura $R$, Yokoyama $Y$, Shigeto $T$, Futagami $M$, Mizunuma $H$. Inhibitory effect of carbonyl reductase 1 on ovarian cancer growth via tumor necrosis factor receptor signaling. Int J Oncol 2015; 47: 2173-2180.

Trop J Pharm Res, November 2016; 15(11): 2349 
12. Sambrook J, Russell D. Molecular Cloning: A Laboratory Manual: Cold Spring Harbor Laboratory Press 2001, Cold Spring Harbor, New York.

13. van Horssen $R$, ten Hagen TL, Eggermont AM. TNF- $\alpha$ in cancer treatment: molecular insights, antitumor effects, and clinical utility. Oncologist 2006; 11: 397-408.

14. Wajant $H$. Principles of antibody-mediated TNF receptor activation. Cell Death Differ 2015; 22: 1727-1741.

15. Wang CY, Mayo MW, Baldwin AS. TNF-and cancer therapy-induced apoptosis: potentiation by inhibition of NF-KB. Science 1996; 274: 784-787.
16. Wang $Y$, Wu TR, Cai S, Welte $T$, Chin YE. Stat1 as a component of tumor necrosis factor alpha receptor 1 TRADD signaling complex to inhibit NF-KB activation. Mol Cell Biol 2000; 20: 4505-4512.

17. Yun H, Park K, Kim E, Han S, Yoon DY, Hong J. IL-32a suppresses colorectal cancer development via TNFR1mediated death signaling. Oncotarget 2015; 6: 9061 9072. 